\section{Mandatory dividend and corporate investment: a multi-country analysis}

Dividend and corporate investment

\author{
Daniel Vancin
}

PPG Ciências Contábeis, Unisinos - Campus de Porto Alegre, Porto Alegre, Brazil, and

Guilherme Kirch UFRGS, Porto Alegre, Brazil
Received 18 May 2019 Revised 4 October 2019 Accepted 10 February 2020

\begin{abstract}
Purpose - This paper aims to empirically verify the impact of the mandatory dividend law on the investment of publicly traded companies.

Design/methodology/approach - The sample includes 212,595 observations from publicly traded companies from 47 different countries over the period from 2000 to 2016. The authors estimated a regression model by panel data methods to show the impact of the mandatory dividend on firm's investment, more specifically in their sensitivities of investment to cash flow and to growth opportunities. In addition, the average treatment effect on the treated was estimated through sample matching.

Findings - The results indicate that the mandatory dividend have a direct and indirect impact on corporate investment.

Originality/value - Legislators and economic agents can use the results of the present research to evaluate the continuity or implementation of this legal mechanism (mandatory dividend) to evaluate economic moments favorable to its use or to create different legal rules to smooth the impact of this mechanism on the investment of companies.
\end{abstract}

Keywords Mandatory dividend, Corporate investment, Financial restriction

Paper type Research paper

\section{Introduction}

Usually, the decision to pay dividends is discretionary and attributed to the management of the companies and their shareholders. However, in some cases, it is also a mandatory decision by the government. For example, the minimum payment of dividends is

(C) Daniel Vancin and Guilherme Kirch. Published in RAUSP Management Journal. Published by Emerald Publishing Limited. This article is published under the Creative Commons Attribution (CC BY 4.0) license. Anyone may reproduce, distribute, translate and create derivative works of this article (for both commercial and non-commercial purposes), subject to full attribution to the original publication and authors. The full terms of this license may be seen at http://creativecommons.org/ licences/by/4.0/legalcode

This work was carried out with the support of the Coordination for the Improvement of Higher Education Personnel Brazil (CAPES).

The authors contributed to the paper in the following ways: Vancin, Daniel, Corresponding Author, Conceptualization (Equal), Data curation (Equal), Formal analysis (Equal), Funding acquisition (Equal), Investigation (Equal), Methodology (Equal), Project administration (Equal), Resources (Equal), Software (Equal), Validation (Equal), Visualization (Equal), Writing-original, draft (Equal), Writing-review and editing (Equal), Kirch, Guilherme.

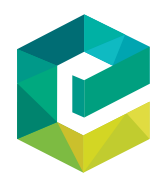

RAUSP Management Journal Vol. 55 No. 4,2020 pp. $531-545$

Emerald Publishing Limited DOI 10.1108/RAUSP-05-2019-0113 
RAUSP

55,4

\section{2}

compulsory in Brazil, Chile, Colombia, Greece and Venezuela (Laporta et al., 1998; Martins \& Novaes, 2012).

These countries share at least one factor in common: they all have their legal systems based on French civil law. According to Laporta et al. (2000), countries that adopt French civil law are characterized by having a low degree of investors protection. Thus, the objective of establishing a minimum mandatory dividend would be the protection of the minority shareholder, by preventing the possibility for controlling shareholders to retain all profits (Laporta et al., 2000; Coelho, 2002). At the same time, it would also have the function of strengthening the capital market by guaranteeing investors a minimum return on their capital. Most of the time, the controlling shareholder cut the distribution of dividends to increase retained earnings to maintain power over the largest amount of resources as these remain in the company's cash holdings, while the dividends go to the shareholders' pockets.

However, the compulsory distribution of part of the companies' profits can directly affect their investments, especially in countries with poor investors protection, due to the difficulty of obtaining external resources by companies in these countries[1]. The cash flow used for this distribution could also (instead) be used to finance projects that are economically favorable to companies. In this way, dividends can act as an investment limiting mechanism, thereby harming shareholders themselves.

According to Fazzari et al. (1988), if the cost of internal financing of a company differs substantially from the cost of external financing, then that company depends on its cash flow to invest. The authors demonstrate that credit restrictions play an important role in firms' investment decisions, with the availability of internal resources (cash flows) having a positive and statistically significant effect on corporate investment, especially for firms classified as financially restricted.

In this context, because the mandatory dividend reduces the available amount of cash inside companies, this research seeks to investigate the impact of the compulsory dividend on corporate investment of publicly traded companies around the world. The hypothesis is that companies located in countries that instituted the mandatory dividend have lower levels of investment and greater sensitivity of investment to cash flow than similar companies located in countries without this obligation, even controlling for other variables such as institutional environment and economic and financial development. The selected sample includes 212,595 observations from publicly traded companies from 47 different nations over the period from 2000 to 2016. We extracted their accounting data from the Compustat ${ }^{\circledR}$ Global database and macroeconomic data from the World Bank.

So, to test the impact of the mandatory dividend on business investment in a multicountry environment, we created an econometric model based on and adapted from the work of Fazzari et al. (1988) and McLean et al. (2012). The regression, with panel data, sought to show how different variables impact firms' investment, and more importantly, their sensitivity to cash flow and to growth opportunities (Tobin's Q). The results showed that companies in countries that institute the mandatory dividend have lower investment levels, higher investment sensitivity to cash flow and lower investment sensitivity to investment opportunities than companies located in countries without this obligation. These results are in line with our hypothesis and corroborate the evidence presented by McLean et al. (2012).

Subsequently, we estimated the ATE on the treated through sample matching. The purpose was to create two different groups of companies with similar relevant characteristics, but which differ in the adoption of the mandatory dividend by their host countries, to precisely measure the effect of the compulsory dividend on corporate investment. Initially, companies in countries with mandatory dividends (treatment group) 
were paired with companies from all the remaining countries in the sample (control group). Finally, as a robustness test, only Brazilian companies (treatment) were paired with companies from other countries that make up the BRICS (control). In both cases, the results indicate the negative and statistically significant impact of the mandatory dividend on corporate investment.

In summary, the present research seeks to add new knowledge to the literature on investment and financial restriction. By testing the existence of significant impacts of the mandatory dividend on the investment of publicly traded companies, we hope to help different countries to decide whether or not to adopt the compulsory nature of this mechanism. By demonstrating the significant impact on investment, we created an issue to be discussed: the trade-off between protecting shareholders and decreasing companies' investment. Countries that adopt the mandatory dividend or intend to use it can use the results of this research to evaluate the continuity or implementation of this mechanism, to evaluate favorable economic moments for its use or to create different legal rules to soften the impact of the mechanism in the business investment.

For example, our results suggest that the mandatory dividend restricts corporate investment. On the other hand, the institution of the compulsory dividend can protect the minority shareholder against expropriation, especially in countries with weak legal protection. As financial restrictions tend to be accentuated in periods of crisis (Campello et al., 2010) and the risk of expropriation tends to be higher when cash flows are abundant (Jensen, 1986), that is, in periods of great economic growth, our results could endorse a rule of variable mandatory dividend. That is, the percentage of mandatory distribution would vary with the performance of the economy: a lower percentage in periods of crisis when financial restrictions tend to be active and a higher percentage in periods of high economic growth when firms enjoy abundant resources and credit constraints are less relevant.

Previously, Martins and Novaes (2012) tested the impact of the minimum mandatory dividend on the investment of publicly traded Brazilian companies. The authors conclude that this law is effective as the dividend yield in Brazil is higher than that verified in the USA, without making the investments by Brazilian firms more difficult. This research was a pioneer in the topic's investigation and contributed to the beginning of the problem's elucidation. An important limitation of this study was the non-separation of firms between those paying only the mandatory minimum and those paying above. For the latter, the mandatory dividend does not appear to represent a restriction on investment. As firms that pay above the mandatory dividend are the majority among publicly traded firms (Vancin, 2018), it is not surprising that the dividends do not have a negative effect on the corporate investment of Brazilian companies when analyzed as a whole.

Unlike Martins and Novaes (2012), the present work seeks to achieve the research objective based on a multi-country sample. This differentiation will allow us to analyze how the mandatory dividend affects companies located in the different countries that adopt it. With a multi-country sample, we can compare the investment decisions of companies located in countries that adopt the mandatory minimum dividend with the investment decisions of companies located in countries that do not use it. Even if the restriction does not affect all companies in countries that adopt the mandatory dividend, if the restriction is active (binding) for a relevant part of the sample, we should find differences in investment decisions when comparing similar companies operating in countries with and without the institution of the mandatory dividend.

We structured this article into five sections; Section 1 is the introduction. Section 2 presents the literature review and our hypothesis. Section 3 describes the selected sample
Dividend and corporate investment

533 
RAUSP

55,4

and the methods used to test our hypothesis. Section 4 presents the results of this research and in Section 5 we outlined our concluding remarks.

\section{Theoretical review and hypothesis development}

As shown by some empirical studies (Fazzari et al., 1988; Gilchrist \& Himmelberg, 1995; Carpenter \& Guariglia, 2008), companies' internal sources of financing have strong relevance for their investment. Additionally, these surveys demonstrate that this relationship is even stronger for companies considered financially restricted, that is, companies that have some level of difficulty in obtaining external financing for their activities (Campello et al., 2010). In this sense, Almeida and Campello (2007) additionally demonstrate that variables that increase the company's ability to obtain external financing (such as the tangibility of its assets) can also increase investment when companies have imperfect access to credit.

The option to keep profits within the company is also a subject that brings great interest to the academic world. This can be partially explained by the fact that it is a costly option, which is adopted, at different levels, by companies. On the subject, Bates, Kahle and Stulz (2009) demonstrate that, in a sample of North American companies between 1986 and 2006, there is a significant increase in the cash holdings of these companies over the years. According to the authors, the precautionary motive provides a plausible explanation for this secular increase in cash holdings by companies that do not distribute dividends. Under this precautionary theory, companies save money as a protective measure against adverse cash flow shocks. Thus, keeping cash on hand would protect against reducing future investment due to credit restrictions, for example.

Another approach on the importance of cash maintenance is found in Almeida et al. (2004). In this research, the authors argue that the link between a company's financial constraints and its demand for liquidity is a critical determinant of the firm's behavior. According to those authors, companies anticipating financing restrictions in the future, respond to these potential restrictions by accumulating money today. This phenomenon would be valid only for financially restricted companies as non-restricted companies have other means to finance their investments with positive NPV.

Thus, the basic companies' alternatives for the destination of their profits are: to distribute the excess profit to their shareholders, invest it in profitable projects that revert in more profits for the shareholders themselves or even constitute reserves in the form of cash holdings. In this matter lies an essential financial decision of managers: to pay dividends and thus reward the shareholders for their invested capital or not to distribute and, in this way, to show confidence in their investment opportunities that could be lost if dividends were paid.

In Brazil and other countries, these options regarding the allocation of profits are not entirely up to the companies. Due to the existence of the mandatory minimum dividend, companies must distribute a pre-established part of their earnings. Thus, the institution of the mandatory dividend removes part of the companies' discretion regarding the allocation of their internal resources. If access to external financing is restricted and/or costly, the mandatory dividend, by decreasing available internal resources, can affect firms' investments and increase their dependence on cash flow shocks.

In this context, we observe that the mandatory dividend reduces the internal amount of resources available to companies. Thus, we formulate the following H1: companies located in countries that instituted the mandatory dividend have lower investment levels and higher investment sensitivity to cash flow than companies located in countries without this 
obligation, even controlling for other variables such as institutional environment and economic and financial development, for example.

\section{Methods, sample and data collection and processing}

\subsection{Empirical model}

We formulate the following empirical model based on and adapted from the work of Fazzari et al. (1988) and McLean et al. (2012) to test the impact of the mandatory dividend on business investment in a multi-country environment.

$$
\begin{aligned}
I_{\mathrm{i}, \mathrm{t}}= & \alpha_{i}+\alpha_{t}+\alpha_{c, t}+\alpha_{I, t}+\beta_{1} C F_{i, t}+\beta_{2} q_{i, t-1}+\beta_{3}\left(C F_{i, t} X \operatorname{DivM}_{c}\right) \\
& +\beta_{4}\left(q_{i, t-1} X \operatorname{DivM}_{c}\right)+\beta_{5}\left(C F_{i, t} X P_{c}\right)+\beta_{6}\left(q_{\mathrm{i}, \mathrm{t}-1} X P_{c}\right)+\beta_{7}\left(C F_{i, t} \mathrm{XGDP}_{c, t}\right) \\
& +\beta_{8}\left(q_{i, t-1} X \operatorname{GDP}_{c, t}\right)+\varepsilon_{i, t}
\end{aligned}
$$

where:

$$
\begin{aligned}
& \alpha_{i} \quad=\text { company fixed effect; } \\
& \alpha_{t} \quad=\text { year fixed effect; } \\
& \alpha_{c, t} \quad=\text { country-year fixed effect; } \\
& \alpha_{I, t} \quad=\text { industry-year fixed effect; } \\
& \beta_{1-8}=\text { coefficients of the explanatory variables; } \\
& I_{i, t} \quad=\text { investment for company } i \text { in period } t \text {. This measure consists of the annual }
\end{aligned}
$$

According to the arguments and evidence presented by McLean et al. (2012), investment sensitivity to Tobin's Q (cash flow) should be higher (lower) in countries with high investors protection, vis-à-vis countries with low investor protection. Thus, we expect the coefficient $\beta_{6}$ to be positive and coefficient $\beta_{5}$ to be negative. According to the hypothesis formulated and the arguments presented here, companies in countries that instituted the mandatory dividend have lower levels of investment, higher sensitivity of investment to cash flow and
Dividend and corporate investment 
RAUSP

55,4

less sensitivity of investment to Tobin's $Q$ than companies located in countries without this obligation. Thus, we expect that coefficient $\beta_{4}$ is negative and coefficient $\beta_{\underline{3}}$ is positive.

One should note that the $\operatorname{DivM}_{c}$ and $P_{c}$ variables do not vary over the sample period. Therefore, and as in McLean et al. (2012), we cannot include these variables at level in a model with firm fixed effects, only their interactions with time-varying variables (Tobin's Q and cash flows). Additionally, due to the variable of interest (Div $M_{c}$ ) varying only at the country level, we cluster the standard errors of the regressions at this level.

\subsection{Model with paired sample}

To directly estimate the effect of the mandatory dividend on companies' investment, the approach adopted was to determine the ATE on the treated through sample matching. The method consists of separating individuals into two groups (treatment and control), considering observable characteristics. The objective is to create two different groups of companies with similar features, but that differ in the adoption of the mandatory dividend by the host countries, in order, in this way, to be able to isolate the effect of the compulsory dividend on the companies' investment.

The treatment variable is the dummy variable $\operatorname{Div} M_{c}$ (which takes on a value of one when the country adopts the mandatory dividend and 0 otherwise). Therefore, the treatment group is made up of companies in countries that embrace the mandatory dividend. In contrast, the control group consists of similar companies, but in countries that do not adopt this legal mechanism.

In this methodological procedure, the objective is to create a control group as similar as possible to the treatment group - but differing on the mandatory dividend's adoption. Thus, conditioning on some variables, it is possible to compare the two groups as if it were a random experiment. The variables selected for this pairing are those listed in the empirical model of the previous section, that is:

- Cash flow $\left(C F_{i, t}\right)$.

- Investment opportunity $\left(q_{i, t-1}\right)$.

- Investor protection $\left(P_{c}\right)$.

- Gross Domestic Product $\left(G D P_{c, t}\right)$.

In addition to these variables, we added three more variables to make the pairing as accurate as possible. They are size, year and economic sector. The size is given by the decile classification of the natural logarithm of the company's total assets, with the ordering done by the country. We based the economic sector on the two-digit rating of the NAICS code. For matching purposes, we use the propensity score matching method, as suggested by Rosenbaum and Rubin (1983).

\subsection{Sample, data collection and processing}

We extracted the data referring to the companies' financial statements from the Compustat $\mathrm{Global}^{\circledR}$ database and macroeconomic data from the World Bank (only the GDP variable). The period selected for this study was the interval between 2000 and 2016, as it represents a long enough period in which different global and local economic conditions can be taken into account. The initial sample consisted of all publicly traded companies in the database mentioned above for the chosen period, totaling 400,072 observations. Of these, we excluded those from the financial sector (73,155 observations) and those with missing data $(103,866)$. Also, we excluded observations with negative net worth $(7,051)$ and total assets less than one million dollars $(3,405)$ to avoid possible measurement bias in the sample. So, the final 
sample consists of 212,595 observations from publicly traded companies from 47 countries covering all continents.

To avoid the outliers' influence in the estimation of our econometric models, we performed the winsorization of the variables. This method of treating outliers consists of trimming the extreme values (below or above the defined minimum and maximum percentiles, respectively), replacing them with the lowest and highest values remaining in the distribution (Lusk et al., 2011). In this study, we fixed as a lower and an upper limit: 1\% and $99 \%$, respectively.

\section{Results}

In Table 1, we show the descriptive statistics[2] for the variables included in our econometric model. The first interesting point to note is the number of companies/year collected for the study: 212,595. Among these, only 7,690 (3.62\%) are from countries that have instituted the mandatory dividend. That is, the vast majority of countries selected for the study do not adopt this legal mechanism[3].

By analyzing the median values of the distributions, we observe that the countries with the highest levels of corporate investment are those that do not adopt the mandatory dividend (0.015). Those who adopt have lower levels for this variable (0.011), i.e. a first indication of the interference of this law in the investment policy of companies.

The next variables to have their descriptive statistics analyzed are cash flow $\left(C F_{i, t}\right)$ and Tobin's Q $\left(q_{t-1}\right)$. These variables are important and recurrent in most investment models found in the literature. The first one measures the amount of resources generated by the company and the second its investment opportunities.

When analyzing the median of the variable $C F_{i, t}$, we note that the countries with the highest cash flows of publicly traded companies are those that institute the mandatory dividend. In other words, at the median, countries with mandatory dividends have a high corporate cash flow vis-à-vis countries without this mechanism. In a similar way, when analyzing the median of the $q_{i, t-1}$ variable, it is also observed that companies in countries with mandatory dividends have higher levels for this variable. Thus, we can infer that companies in Brazil, Chile, Colombia, Greece and Venezuela, for the selected period and according to the proposed measurement of the variables, have higher cash flows and Tobin's Q. Still, this fact is not reflected in greater investment.

The analyzes carried out up to this point are based on microeconomic data; that is, companies are the object of study. The next variables to have their results detailed are $G D P_{c, t}$ and $P_{c}$ - macroeconomic data. This kind of data seeks to measure the characteristics of the economy and legislation of the country as a whole.

Analyzes on the $P_{c}$ variable must consider that this construct is time-invariant; that is, there is no variability over the sample period ( $\sigma$ equals to 0 in this dimension). It seeks to quantify the protection given to investors in the most different nations. We observe that the countries that instituted the mandatory dividend have low levels of the $P_{c}$ variable, showing values for this variable lower than the sample median. This result was part of the initial expectations of the research as the mandatory dividend would have the purpose of precisely remedying the weak legal protection for investors in these countries.

We extract the GDP data from the World Bank database. The natural logarithm of GDP per capita of the different nations in the sample is used for our analysis. The purpose of inserting this variable is to control for macroeconomic factors, such as the wealth and level of economic development in the country that may influence a corporation's investments and even the decision to adopt or not the mandatory dividend. According to the evidence presented in McLean et al. (2012, p. 315), "[...] resources are allocated more efficient and
Dividend and corporate investment 
RAUSP

55,4

\section{8}

Table 1.

Descriptive statistics of the variables

selected for the study

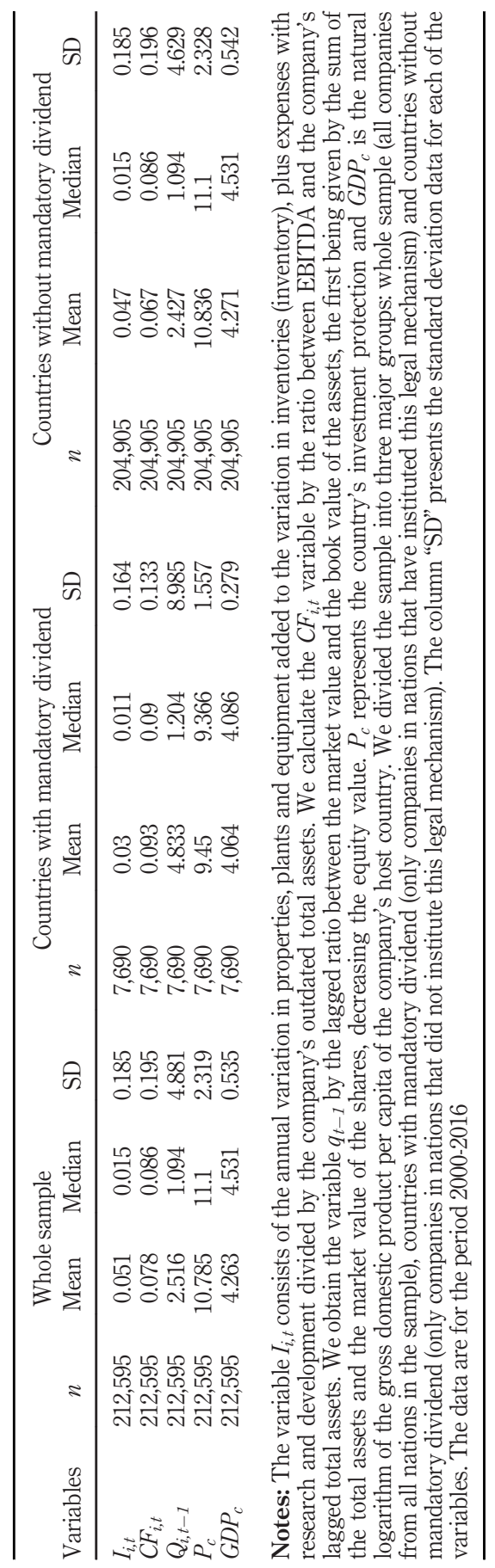


financial constraints are less binding in wealthier countries." By analyzing the median, we can see that countries that instituted the mandatory dividend have levels of the variable $G D P_{c, t}$ below the median of the overall sample. These results were already expected, as the first group of countries is recognized for their low levels of human and economic development.

Thus, the results obtained by the analysis of the descriptive statistics of the variables listed in this research demonstrate that companies in countries with mandatory dividends have, at the median, lower levels of investment but with high cash flows and investment opportunities. These microeconomic characteristics add to those recently observed at the macroeconomic level $-G D P_{c, t}$ and $P_{c}$. That is, these companies are from countries with low legal protection for investors and with the gross domestic product below the global median. We summarize the way these variables interact together in our econometric model in Table 2.

The econometric model presented aims to test the impact of the mandatory dividend on corporate investment in a multi-country environment. The regression, with panel data, seeks to show different variables that impact the investment of firms, controlling for fixed effects of the company, year, country-year and industry-year. In all, the model was estimated using 212,595 observations over 16 years (2000-2016), that is, a very representative sample.

The two microeconomic variables, recurring in investment models, attracted coefficients with the expected signals. Both cash flows $\left(C F_{i, t}\right)$ and investment opportunities $\left(q_{i, t-1}\right)$ have positive coefficients. That is, the higher a company's cash flows and Tobin's $\mathrm{Q}$, the higher the company's investment is likely to be. Then, when placed alone in the model (according to Regression 1), both are statistically significant at the $1 \%$ level.

However, only $C F_{i, t}$ is statistically significant at $1 \%$ when we analyze the complete model. In Regression 2, the variable $q_{i, t-1}$ loses part of its statistical significance. From this

\begin{tabular}{|c|c|c|c|}
\hline Variables & $\begin{array}{l}\text { (1) } \\
I_{i, t}\end{array}$ & $\begin{array}{l}\text { (2) } \\
I_{i, t}\end{array}$ & $\begin{array}{l}\text { (3) } \\
I_{i, t}\end{array}$ \\
\hline$C F_{\mathrm{i}, \mathrm{t}}$ & $0.16^{* * * *}(10.52)$ & $1.50^{* * * * *}(7.46)$ & $1.18^{* * * *}(4.97)$ \\
\hline$q_{i, t-1}$ & $0.006^{* * * *}(10.37)$ & $0.00^{* *}(2.58)$ & $0.00(0.11)$ \\
\hline$C F_{i, t} \times \operatorname{Div}_{c}$ & & $0.23^{*}(10.75)$ & $0.17^{*}(1.83)$ \\
\hline$q_{i, t-1} \times \operatorname{DivM}_{c}$ & & $-0.00^{* * * *}(-2.84)$ & $-0.00(-0.07)$ \\
\hline$C F_{i, t} \times P_{c}$ & & $-0.06^{* *}(-2.37)$ & $-0.06^{* *}(-2.49)$ \\
\hline$q_{i, t-1} \times P_{c}$ & & $0.00^{\text {****** }}(2.79)$ & $0.00(0.02)$ \\
\hline$C F_{i, t} \times G D P_{c, t}$ & & $-0.15^{* *}(-2.13)$ & $-0.05(-0.61)$ \\
\hline $\begin{array}{l}q_{i, t-1} \times G D P_{c, t} \\
\sigma C F_{i+}\end{array}$ & & $-0.00^{* *}(-2.65)$ & $\begin{array}{r}-0.00(-0.07) \\
0.31^{* * * *}(12.2)\end{array}$ \\
\hline Constant & $-0.04(-0.00)$ & $-0.10(0.00)$ & $-0.06(-0.01)$ \\
\hline Observations & 212,595 & 212,595 & 123,695 \\
\hline$R^{2}$ & 0.07 & 0.09 & 0.08 \\
\hline Firms FE & Yes & Yes & Yes \\
\hline Year FE & Yes & Yes & Yes \\
\hline Industry-year FE & Yes & Yes & Yes \\
\hline County-year FE & Yes & Yes & Yes \\
\hline Period & $2000-2016$ & $2000-2016$ & $2000-2016$ \\
\hline
\end{tabular}

Notes: The "variables" column shows all variables included in the model. The regression had the dependent variable $I_{i, t}$, that is, investment variable of the company $i$ in period $t$ - this measure consists of the combination of the annual growth in properties, plants and equipment, added to the growth in the inventory, plus expenses with research and development. The acronym EF stands for fixed effect. The data are for the period 2000-2016. We extracted these multi-country data from Compustat Global ${ }^{\circledR}$. The $t$-statistic is in parentheses, in which ${ }^{* * * *} p<0.01 ;{ }^{* * *} p<0.05 ;{ }^{*} p<0.1$

Source: elaborated by authors
Dividend and corporate investment

539 
RAUSP

55,4

fact, we can infer that cash flow has greater relevance in explaining corporate investment than the investment opportunities that companies may have.

To understand the impact of the mandatory dividend $\left(D i v M_{c}\right)$ on the investment of companies $\left(I_{i, t}\right)$, it is essential to highlight the fact that this dummy variable does not vary over the sample period. As we use a model of fixed effects, we do not include the $\operatorname{Div} M_{c}$ variable at level, as variables that do not vary over time have no explanatory power in a fixed-effects regression.

Because of this fact, we sought to evaluate the interaction of the variable mandatory dividend $\left(\operatorname{Div}_{c}\right)$ with Tobin's Q and cash flow variables. According to our hypothesis, investment of companies in countries that have instituted the mandatory dividend are more sensitive to cash flows than investment of companies located in countries without this obligation. According to the results of the $C F_{i, t} \times D i v M_{c}$ interaction coefficient, this expectation is confirmed. The sign of this coefficient is positive and statistically significant.

In countries that do not adopt the mandatory dividend, the total amount of cash flows can be used to carry out the company's investments. In countries that use this legal provision; however, the total amount of cash flow cannot be used in full for investments, as a portion must be distributed to shareholders. Thus, the result obtained shows that companies in countries with mandatory dividends are even more dependent on their cash flows to finance their activities. In other words, the compulsory payment of part of their profits may be harmful, as they are highly dependent on their internal sources for finance. This result contrasts with those reported by Martins and Novaes (2012), as it suggests that the mandatory dividend restricts companies' investment. This divergence may be the result of differences between the approach of the present study and that used by Martins and Novaes (2012), as emphasized in the introduction.

The negative and statistically significant sign of the coefficient of the interaction $q_{t-1} \times D i v M_{c}$ indicates that companies in countries with mandatory dividends have their investment less dependent on their investment opportunities. This result is also consistent with our argument that the compulsory dividend makes corporate investment more dependent on the internal availability of resources and, therefore, less sensitive to investment opportunities. Another possible explanation is that the mandatory dividend may not be an efficient tool for investor protection, while there may be ways to "get around" this compulsory payment.

It is important to note that we planned the use of the interactions of Tobin's $\mathrm{Q}\left(q_{i, t-1}\right)$ and cash flows $\left(C F_{i, t}\right)$ with investors protection $\left(P_{c}\right)$ and $G D P_{c, t}$ to control for other effects at the country level that affect firm's investment and that may be related to the decision to adopt or not the mandatory dividend rule. As in McLean et al. (2012), investment sensitivity to Tobin's Q (cash flows) is higher (lower) in countries with strong legal protection.

Following the suggestions of an anonymous reviewer and as a test of robustness, we reestimated our original regression using a new control variable for corporate investment: cash flow volatility $\left(\sigma C F_{i}, t\right)$. We estimated it through the standard deviation of the companies' cash flow over the past five years. We included this variable in Regression model 3 . We can observe that this variable has a positive and statistically significant coefficient, a fact that contradicts a priori expectation that companies with more volatile cash flow would invest less due to the increased uncertainty presented. In terms of signs, the other coefficients remain the same as in the Model 2.

In short, cash flows are more critical for companies in countries that have instituted the mandatory dividend. Then this legal provision is precisely a compulsory reduction of these cash flows that could be used for investments. Consequently, the compulsory dividend in the multi-country sample indicates that it is a detrimental factor for corporate investment as it reduces the own resources of those companies that are most dependent on it. As sensitivity 
to Tobin's Q is lower in these countries, and this indicates a possible scenario of weaker legal protection, perhaps the benefit advocated by legislators (increased investor protection) will not be met or will not exceed, its linked costs.

\subsection{Model with paired sample}

To directly test the impact of the mandatory dividend on corporate investment in a multicountry environment, it is necessary to create a matched sample of firms. In other words, a sample composed of companies located in countries with similar institutional and economic environments and similar in their microeconomic characteristics, but which differ in the adoption of the mandatory dividend. The aim is to isolate the effect of the mandatory dividend rule on firm's investment.

We estimate the propensity score matching to match the sample. The objective is to create a control group as similar as possible to the treatment group - differing only on the adoption of the mandatory dividend. Thus, conditioning on some variables, it is possible to compare the two groups as if it were a random experiment. The variables selected for this matching procedure are:

- $\quad$ cash flow $\left(C F_{i, t}\right)$;

- investment opportunity $\left(q_{i, t-1}\right)$;

- investors protection $\left(P_{c}\right)$;

- gross domestic product $\left(G D P_{c, t}\right)$;

- $\quad$ size = measured by the natural logarithm of the company's total assets;

- year = dummies for the years covered by our sample; and

- $\quad$ economic sector = dummies for the economic sectors of the companies, according to the NAICS two-digit classification - from the Compustat Global ${ }^{\circledR}$ database.

Then, based on the paired sample of firms, it is possible to estimate the ATE on the treated. The treatment variable used for this research is the dummy variable $D i v M_{c}$ (which takes on a value of 1 when the country adopts the mandatory dividend and 0 otherwise). In other words, the objective is to demonstrate the impact of the compulsory dividend (treatment) on corporate investment $\left(I_{i, t}\right)$. We summarize these results of the ATE in Table 3.

The result of the ATE on the treated was -0.013. By analyzing the sign of the coefficient, it appears that the mandatory dividend has a negative impact on corporate investment. In

\begin{tabular}{|c|c|}
\hline Treatment variable: & $\operatorname{Div}_{c}$ \\
\hline $\begin{array}{l}\text { Dependent variable: } \\
\text { ATE }\end{array}$ & $\begin{array}{c}I_{i, t} \\
-0.013^{* * * *} \\
(0.003)\end{array}$ \\
\hline Observations & 15,380 \\
\hline
\end{tabular}

Notes: The regression had the dependent variable $I_{i, t}$, that is, investment variable of the company $i$ in period $t$ - this measure consists of the combination of the annual growth in properties, plants and equipment, added to the growth in the inventory, plus expenses with research and development. The treatment variable was the mandatory dividend $\left(\operatorname{Div} M_{c}\right)$, a dummy that assumes a value of 1 if the country adopts this legal mechanism and 0 otherwise. The data are for the period 2000-2016. We extracted these multi-country data from Compustat Global ${ }^{\circledR}$. The $t$-statistic is in parentheses, in which ${ }^{* * * *} p<0.01$; $* * p<$ $0.05 ; * p<0.1$

Source: Elaborated by authors

Dividend and corporate investment

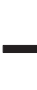

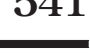


RAUSP

55,4

\section{2}

other words, we show that the compulsory withdrawal of part of the cash flows of companies in countries that adopt this legal mechanism seems to reduce corporate investment as the proposed methodology seeks to isolate this relationship - mandatory dividend and companies' investment.

In addition to being negative, the coefficient is statistically significant at $1 \%$ level. Due to its magnitude, we can infer that the mandatory dividend negatively impacts 0.013 on corporate investment. According to Table 1 , the average investment variable $\left(I_{i, t}\right)$ was 0.051 . It is possible to infer that the mandatory dividend reduces the investment of companies in countries that adopt it by around $25 \%(0.013 / 0.051)$.

To create a robustness test for the results presented in this section, we measure the ATE on the treated for a restricted sample of the BRICS countries - Brazil, Russia, India, China and South Africa. BRICS is an informal economic group of emerging countries, which would have a future potential to overcome the great economic powers. In other words, a group that is minimally cohesive in its economic and perhaps institutional environments. Thus, the primary intention of the robustness test is to verify whether the corporate investment in Brazil is less than the rest of the group's countries due to the mandatory dividend, given that we control the other factors that influence investment. We summarize the results in Table 4.

The results obtained in this restricted sample that includes only the countries that make up the BRICS are similar to those found for the global sample. The result of the ATE on the treated was -0.02 . By analyzing the sign of the coefficient, it appears that the mandatory dividend has a negative impact on corporate investment. In addition to being negative, the coefficient is statistically significant. In terms of economic significance, Brazilian firms, subject to the mandatory dividend, tend to invest $2 \%$ of assets less than their peers residing in other BRICS countries. At the average investment in the whole sample, this represents almost 40\% (0.02/0.051) less investment by Brazilian firms.

In sum, we attempted to create a paired sample of companies, that is, companies with similar characteristics to be able to isolate the effect of the mandatory dividend on the investment of firms. Then, by isolating this effect, it was shown that the compulsory dividend significantly reduces corporate investment. In other words, more evidence on the cost linked to the imposition of a mandatory distribution rule over part of the companies' cash flows by the state.

\section{Concluding remarks}

The required distribution of part of the company's profit can directly affect their investments, especially in the countries that adopt it due to the difficulty of obtaining

\begin{tabular}{lc}
\hline Treatment variable: & $D i v M_{c}$ \\
\hline Dependent variable: & $I_{i, t}$ \\
ATE & $-0.02^{*}$ \\
Observations & $(0.064)$ \\
Source: Elaborated by authors. & 6,740
\end{tabular}

Table 4.

Calculation of the treatment effect for corporate investment in a sample with BRICS countries only
Notes: The regression had the dependent variable $I_{i, t}$, that is, investment variable of the company $i$ in period $t$ - this measure consists of the combination of the annual growth in properties, plants and equipment, added to the growth in the inventory, plus expenses with research and development. The treatment variable was the mandatory dividend $\left(\operatorname{Div} M_{c}\right)$, a dummy that assumes a value of 1 if the country adopts this legal mechanism and 0 otherwise. The data are for the period 2000-2016. We extracted these multi-country data from Compustat Global ${ }^{\mathbb{B}}$. The $t$-statistic is in parentheses, in which $* * * p<0.01$, ** $p<$ $0.05, \stackrel{*}{p} p<0.1$ 
external resources in these countries. In other words, part of the companies' internal sources of financing is removed, a portion that would be essential for investments due to the scarcity of resources. In this context, the objective was to empirically investigate the impact of the mandatory dividend on corporate investment in a multi-country environment.

According to our research hypothesis, companies located in countries that instituted the mandatory dividend have lower levels of investment and greater sensitivity of investment to cash flow than companies located in countries without this obligation, even controlling for other variables such as institutional environment and economic development, for example.

Dividend and corporate investment

When instituting the mandatory dividend in some countries, their companies tend to have less availability of internal resources, which would result in lower investment levels. In this context, countries with greater investor protection have less investment sensitivity to cash flow than countries with less protection (Mclean et al., 2012). The idea tangent to the problem is that protection for shareholders reduces the cost of external financing as by reducing uncertainties, protection consequently decreases the return required by capital. So, companies in countries with more excellent protection should have less investment depending on the companies' cash flow.

The results obtained by the present research demonstrate that companies in countries with mandatory dividends depend even more on their cash flows to finance their activities. Thus, the compulsory payment of part of their profits is even more damaging, as they are highly dependent on their internal sources. Additionally, through the paired sample model, it was demonstrated that the mandatory dividend significantly reduces corporate investment - it reduces companies' investment in the countries that adopt it by around $25 \%$. In other words, more evidence on the cost linked to the imposition of distribution of part of the companies' cash flows by the government.

\section{Notes}

1 Partly as a result of its weak legal protections for investors.

2 The data broken down by country can be found in (VANCIN, 2018), the thesis that originated the present research.

3 The imbalance between the number of observations in each group, countries with and without mandatory dividends, can lead the reader to question the validity of our results. We understand that this imbalance makes it more difficult to find any effect of the mandatory dividend on the investment unless it really exists. As we know, in a regression model there must be sufficient variation in the regressors to identify the parameters. In our case, the variance of the mandatory dividend variable is low, indicating that we may have difficulty identifying the effect of mandatory dividend on firm's investment. Note that when estimating the ATE, the treatment group (with mandatory dividend) and control group (without the mandatory dividend) have the same number of observations. We thank an anonymous referee for making us reflect on this point.

\section{References}

Almeida, H., \& Campello, M. (2007). Financial constraints, asset tangibility, and corporate investment. Review of Financial Studies, 20, 1429-1460. doi: https://doi.org/10.1093/rfs/hhm019.

Almeida, H., Campello, M., \& Weisbach, M. S. (2004). The cash flow sensitivity of cash. The Journal of Finance, 59, 1777-1804. doi: https://doi.org/10.1111/j.1540-6261.2004.00679.x.

Bates, T. W., Kahle, K. M., \& Stulz, R. M. (2009). Why do us firms hold so much more cash than they used to?. The Journal of Finance, 64, 1985-2021. doi: https://doi.org/10.1111/j.15406261.2009.01492.x. 
RAUSP

55,4

Campello, M., Graham, J. R., \& Harvey, C. R. (2010). The real effects of financial constraints: Evidence from a financial crisis. Journal of Financial Economics, 97, 470-487. doi: https://doi.org/10.1016/j. jfineco.2010.02.009.

Carpenter, R. E., \& Guariglia, A. (2008). Cash flow, investment, and investment opportunities: New tests using uk panel data. Journal of Banking \& Finance, 32, 1894-1906. doi: https://doi.org/10.1016/j. jbankfin.2007.12.014.

Coelho, F. U. (2002). Curso de direito comercial. [S.1.]. Saraiva, v. 1,

Fazzari, S., Hubbard, R. G., \& Petersen, B. (1988). Investment, financing decisions, and tax policy. The American Economic Review, 1, 200-205.

Gilchrist, S., \& Himmelberg, C. P. (1995). Evidence on the role of cash flow for investment. Journal of Monetary Economics, 36, 541-572. doi: https://doi.org/10.1016/0304-3932(95)01223-0.

Jensen, M. C. (1986). Agency cost of free cash flow, corporate finance, and takeovers. Corporate finance, and takeovers. American Economic Review, 76

Laporta, R., Florencio, L. D. S., \& Shleifer, A. (1998). Law and finance. Journal of Political Economy, 106, 1113-1155.

Laporta, R., Florencio, L. D. S., Shleifer, A., \& Vishny, R. W. (2000). Agency problems and dividend policies around the world. The Journal of Finance, 55, 1-33.

Lusk, E. J., Halperin, M., \& Heiling, F. (2011). A note of power differentials in data preparation between trimming and winsorizing. Business Management Dynamics, 1, 23-31.

Mclean, R. D., Zhang, T., \& Zhao, M. (2012). Why does the law matter? Investor protection and its effects on investment, finance, and growth. The Journal of Finance, 67, 313-350. doi: https://doi. org/10.1111/j.1540-6261.2011.01713.x.

Martins, T. C., \& Novaes, W. (2012). Mandatory dividend rules: Do they make it harder for firms to invest?. Journal of Corporate Finance, 18, 953-967. doi: https://doi.org/10.1016/j. jcorpfin.2012.05.002.

Rosenbaum, P. R., \& Rubin, D. B. (1983). The central role of the propensity score in observational studies for causal effects. Biometrika, 70, 41-55. doi: https://doi.org/10.1093/biomet/70.1.41.

Vancin, D. F. (2018). Investimento, Distribuição de Lucro e Regulação: o impacto do dividendo obrigatório no investimento corporativo. Tese (Doutorado) — PPGA/UFRGS,

\section{Appendix 1. Formulation of the investors protection variable}

The investors protection $\left(P_{c}\right)$ variable is based on the classic research by Laporta et al. (1998). In this article, the authors examine the laws that protect shareholders and use some indicators to measure the degree of protection for investors in 49 countries. Our intention is to control the institutional environment factor, to remove its effect from the econometric model. That is, test the impact of the mandatory dividend on corporate investment, considering that different countries have different institutional environments.

Its calculation is simple, being the sum of the nine items listed below - the higher the $P c$ indicator, the greater the protection given to a nation's investor.

(1) One share - one vote: Variable with a value equal to 1 when the country's corporate law or commercial code requires that common shares have the right to one vote per share and 0 otherwise. Similarly, this variable receives the value 1 if the law prohibits the existence of ordinary shares with the right to multiple or non-voting votes, also prohibiting companies from stipulating a maximum number of votes per shareholder regardless of the number of shares held and 0 if the opposite.

(2) Voting by e-mail allowed: Equals 1 when the country's corporate law or commercial code allows shareholders to send their votes to the company by e-mail and 0 otherwise. 
(3) Blocked shares before shareholders meetings: Equals 1 when the country's corporate law or commercial code does not allow companies to oblige their shareholders to deposit their shares before shareholders' meetings, to prevent the sale of their shares for a certain number of days and 0 otherwise.

(4) Cumulative voting or proportional representation: Equals 1 when the country's corporate law or commercial code allows shareholders to cast all their votes for a candidate for election to the board of directors (cumulative voting) or allows for a proportional representation mechanism on the board where minorities can nominate a

Dividend and corporate investment proportional number of representatives and 0 otherwise.

(5) Oppressed minority rights: This variable has a value equals to 1 when the country's corporate law or commercial code grants minority shareholders a judicial possibility to appeal administrative decisions or the right to leave the company requiring it to buy its shares when there are fundamental changes, such as mergers, asset provisions or changes to the articles of association; and 0 otherwise.

(6) Preemptive right for new issues: Equals 1 when the country's corporate law or commercial code first grants shareholders the opportunity to purchase newly issued shares, and this right can be waived only by the shareholder vote and 0 otherwise.

(7) Percentage of capital needed to call an extraordinary meeting: The minimum percentage of shares that grant a shareholder the right to request an extraordinary shareholders' meeting. This indicator ranges from $1 \%$ to $33 \%$.

(8) Anti-director rights: This variable adds some shareholder rights that Laporta et al. (1998) calls it "anti-director rights." The variable is formed by adding 1 when:

- the country allows the shareholder vote by correspondence for the company;

- shareholders are not obliged to deposit their shares before meetings;

- cumulative voting or proportional representation in the board is allowed;

- there is an oppressed minority mechanism;

- the percentage of share capital required to call an extraordinary meeting is less than or equal to $10 \%$ - the median of the sample found by the aforementioned authors; and

- the shareholders have preferential rights that can only be waived only by the vote of the shareholder himself. Thus, this indicator ranges from 0 to 6 .

(9) Applicability of laws: This indicator seeks to close the gap between legislation and its actual use in different nations. After all, there is a possibility that nations may have laws that protect shareholders, but that are not enforced in practice. For this reason, Laporta et al. (1998) created an indicator of the applicability of laws, based on data from the international country risk guide, which assesses the law and its tradition. The indicator ranges from 0 to 10 , where the lower this indicator, the worse the applicability of the law.

\section{Corresponding author}

Daniel Vancin can be contacted at: daniel_vancin@hotmail.com

Associate Editor: Wilson Toshiro Nakamura

For instructions on how to order reprints of this article, please visit our website:

www.emeraldgrouppublishing.com/licensing/reprints.htm

Or contact us for further details: permissions@emeraldinsight.com 